\title{
Cervical cancer screening coverage in urban and rural areas in Southeast Sulawesi: its determinants
}

\author{
Juminten Saimin ${ }^{1 *}$, Satrio Wicaksono ${ }^{2}$, Ashaeryanto ${ }^{2}$ \\ ${ }^{1}$ Department of Obstetrics and Gynecology, Faculty of Medicine, Halu Oleo University, \\ ${ }^{2}$ Department of Biomedicine, Faculty of Medicine, Halu Oleo University, Southeast \\ Sulawesi, Indonesia
}

DOI: http://dx.doi.org/10.19106/JMedScie/0050032018012

\section{ABSTRACT}

Cervical cancer is a woman's health problem that is still widespread throughout the world, especially in developing countries such as Indonesia. The high incidence of cervical cancer is related with early detection program. Visual inspection of acetic acid (VIA) is used as an alternative screening method because it is easier, cheaper and its effectiveness is not much different from the Pap test. There are differences on coverage of VIA test in urban and rural areas. This study aimed to identify determinants of cervical cancer screening coverage in urban and rural areas. The study was a cross sectional study. Total of 372 women who did the VIA test in urban areas of Kendari and rural areas of South Konawe in January to June 2016 were included in this study. Coverage of cervical cancer screening was examined in relation to the level of education, knowledge, distance of health facilities and family support. The data was analyzed using Chi-square test with a significance value $p<0.05$. The majority of respondents were the age groupof 31-40 years old, low parity, and first intercourse at $\geq 17$ years old. There were significant difference of education level $(p=0.000)$, knowledge $(p=0.000)$ and distance of health facilitiesin urban and rural areas $(p=0.000)$. There was no significant differences between family support in urban and rural areas $(p=0.224)$. In conclusions, education level, knowledge, and distance of health facilities are determinants of cervical cancer screening coverage in urban and rural areas in Southeast Sulawesi.

\section{ABSTRAK}

Kanker cervik adalah masalah kesehatan perempuan diseluruh dunia, terutama di Negara berkembang seperti Indonesia. Resiko tinggi terhadap kanker cervik berkaitan dengan program deteksi dini. Visual inspection of acetic acid (VIA) digunakan sebagai metode pemeriksaan alternatif karena mudah, murah, dan efektif, tidak berbeda jauh dari tes Pap. Terdapat perbedaan pada cakupan VIA yang digunakan di daerah urban dan pedesaan. Penelitian ini bertujuan untuk mengidentifikasi faktor penentu dari cakupan deteksi kanker cervik di daerah urban dan pedesaan. Penelitian ini merupakan penelitian cross sectional. Sebanyak 372 perempuan yang melakukan VIA test di Kendari (daerah urban) dan Konawe Selatan (daerah pedesaan) pada rentan bulan Januari hungga Juni 2016 berpartisipasi pada penelitian ini. Cakupan pemeriksaan kanker cervik diperiksa keterkaitannya antara tingkat pendidikan, pengetahuan, dukungan keluarga, dan jarak tempat tinggal dengan fasilitas kesehatan. Analisis data dilakukan dengan uji Chi-square dengan nilai signifikansi $p<0.05$. sebagian besar responden berumur 31-40 tahun, paritas rendah, dan berhubungan intim pertama kali pada $\geq 17$ tahun. Hasil menunjukkan adanya perbedaan signifikan pada tingkat pendidikan $(p=0.000)$, pengetahuan $(p=0.000)$ dan jarak antara tempat tinggal dan fasilitas kesehatan $(p=0.000)$. Tidak terdapat perbedaan yang signifikan pada dukungan keluarga pada daerah urban maupun pedesaan $(p=0.224)$. 
Kesimpulan yang dapat diperoleh adalah tingkat pendidikan, pengetahuan, dan jarak tempat tinggal dan fasilitas kesehatan menentukan cakupan pemeriksaan kanker servik pada daerah urban dan pedesaan di Sulawesi Selatan.

Keywords: distance of health facilities - education - knowledge - cervical cancer determinants

\section{INTRODUCTION}

Cervical cancer is a woman's health problem that is still widespread throughout the world, especially in developing countries such as Indonesia. In 2012, cervical cancer was the fourth most common cancer among women in worldwide. Around 528,000 new cases of cervical cancer were reported in 2012 and around $85 \%$ of cases occurred in developing countries. Around 266,000 women died of cervical cancer and around $87 \%$ of these deaths occurred in developing countries. ${ }^{1}$ The high incidence of cervical cancer were related with early detection program. The incidence of cervical cancer in developed countries was fewer than in developing countries, due to public awareness for early detection and prevention program. $^{2-4}$

The majority of cervical cancer case (about 70\%) is diagnosed at an advanced stages (stage IIb or more). ${ }^{5}$ The majority of cervical cancer patients come to the clinic when symptoms have appeared and usually advanced stage. ${ }^{2,4}$ The treatment of advanced cervical cancer is more difficult, expensive, unsatisfied results and low life expectancy. ${ }^{6}$

The problem of cervical cancer in developing countries is associated with early detection program that still encountered many obstacles. ${ }^{2,4}$ Some problems that were found such as facilities for cervical cancer screening, culture, family support, attitude, knowledge and education. Those problems affect difficulty to diagnose early cervical cancer. ${ }^{2,4,7-9}$ Inadequate health care and public health infrastructure, competing health priorities, and poverty prevent gaining traction of prevention programs. ${ }^{10}$
Cytology-based screening strategies have been effective in reducing rates of cervical cancer in the United States and other developed countries. Cytology-based screening is infeasible in low-resource settings, because they need skilled personnel, laboratory equipment, transporting and storing of cervical specimens. ${ }^{11}$

Visual inspection of acetic acid (VIA) is used as an alternative screening test of cervical cancer especially in developing countries. Effectiveness of VIA is not much different from Pap test. Moreover, it is easier and cheaper than the Pap test. The VIA test can be performed in primary health care due to the very simple equipment needed. In addition, the results can be immediately provided because it does not require repeated request, wider coverage, and no expert screener is required to examine the samples. ${ }^{4,11,12}$

There are differences on coverage of VIA test in urban and rural areas in Southeast Sulawesi. There were $7.56 \%$ of women who conducted VIA test in LepoLepo Healthcare in Kendari City. While in Landono Healthcare in South Konawe District, there were $26.3 \%$ of women who conducted VIA test. ${ }^{13}$ This study aimed to identify determinants of cervical cancer screening coverage with VIA test in urban and rural areas in Southeast Sulawesi. The data would be used to plan constructively steps in preparing early detection programs of cervical cancer with VIA test. For community health services, this study is conducted as suggestion to make activities that improve service quality and increase promotion and preventive efforts. 


\section{MATERIALS AND METHODS}

\section{Sample specificity}

This study was a quantitative research with cross sectional design. The population was women of childbearing age who used VIA test in Lepo-Lepo Healthcare in Kendari City and Landono Healthcare in South Konawe District, Southeast Sulawesi. The study was conducted in a period of January to June 2016. Samples were selected by consecutive sampling and were previously provided by informed consent. The inclusion criteria were patients aged 20-50 years old, married, and never had a hysterectomy. The exclusion criteria were incomplete questionnaires. Protocol of the study has been approved by the Research Ethics Committee of the Faculty of Medicine, Halu Oleo University, Southeast Sulawesi.

\section{Data collection}

Determinants of cervical cancer screening covered education background, knowledge, distance of health facilities and family support. The cervical cancer screening was the women who comes and performs cervical cancer screening by VIA test. Education was the level of formal education that has been followed. Knowledge was the ability to answer correctly related to the questions on knowledge of cervical cancer. Distance of health facilities was distance from women's house to service facilities of VIA test according to her perception. Family support was a family attitude given to perform early detection cancer with VIA test.

\section{Statistical analysis}

Data were presented as frequency and analyzed by SPSS for Windows version 16 . The data were analyzed by Chi-square test with a significance value $\mathrm{p}<0.05$.

\section{RESULTS}

A total of 372 respondents involved in this study. The characteristics of respondents are presented in TABLE 1 . The largest age group of respondents was 31-40 years old. The majority of respondents were low parity and first sexual intercourse at the age of more than 17 years old. The majority of respondents were workers. The family incomes of respondents in urban areas were greater than in rural areas.

TABLE 1.Characteristics of respondents

\begin{tabular}{lcccc}
\hline \multirow{2}{*}{ Characteristics } & \multicolumn{2}{c}{ Urban } & \multicolumn{2}{c}{ Rural } \\
\cline { 2 - 5 } & $\mathrm{n}$ & $\%$ & $\mathrm{n}$ & $\%$ \\
\hline Age (years old) & & & & \\
- $20-30$ & 83 & 17.8 & 60 & 32.3 \\
- $31-40$ & 72 & 38.7 & 57 & 30.6 \\
- $41-50$ & & & & \\
Parity & 174 & 93.5 & 129 & 69.4 \\
- Low Risk & 12 & 6.5 & 57 & 30.6 \\
- High Risk & & & & \\
The age of first intercourse & & & & \\
- $<17$ years old & 21 & 11.3 & 36 & 19.4 \\
- $\geq 17$ years old & 165 & 88.7 & 150 & 80.6 \\
Occupation & & & & \\
- Work & 99 & 53.2 & 129 & 69.4 \\
- Housewife & 87 & 46.8 & 57 & 30.6 \\
Family income & & & & \\
- Less & 21 & 11.3 & 117 & 62.9 \\
- Enough & 165 & 88.7 & 69 & 37.1 \\
\hline
\end{tabular}

TABLE 2 presented the characteristics of respondents respondents from urban and rural areas consisted education, knowledge, distance of health facilities, and family support. The majority of respondents in urban areas had high education (56.5\%), while respondents in rural areas had basic education $(46.8 \%)$. There were significant differences between the education levels of respondents in urban and rural areas $(p=0.000)$. The majority of respondents in urban and rural areas had sufficient knowledge, but the majority of respondents who had good knowledge were in rural areas $(37.0 \%)$. There were significant differences between the knowledge of respondents in urban and rural areas $(p=0.000)$. Distance of health facilities in urban areas ware close distance $(59.7 \%)$ while the distance in rural 
areas was long distance (69.4\%). There were significant differences between the distance of health facilities in urban and rural areas $(p=0.001)$. Respondents' family support in urban areas was $93.5 \%$ and in rural areas was $87.1 \%$. There was no significant difference between family support in urban and rural areas $(p=0.224)$.

TABLE 2. Education, knowledge, distance of health facilities, and family support of respondents from urban and rural areas.

\begin{tabular}{|c|c|c|c|c|c|}
\hline \multirow{3}{*}{ Characteristics } & \multicolumn{4}{|c|}{ Coverage of VIA test } & \multirow{3}{*}{$\mathrm{p}$} \\
\hline & \multicolumn{2}{|c|}{ Urban } & \multicolumn{2}{|c|}{ Rural } & \\
\hline & $\mathrm{n}$ & $\%$ & $\mathrm{n}$ & $\%$ & \\
\hline \multicolumn{6}{|l|}{ Education } \\
\hline - Basic & 15 & 8.00 & 87 & 46.8 & \multirow{3}{*}{0.000} \\
\hline - Middle & 66 & 35.5 & 75 & 40.3 & \\
\hline • High & 105 & 56.5 & 24 & 12.9 & \\
\hline \multicolumn{6}{|l|}{ Knowledge } \\
\hline - Lack & 33 & 17.7 & 12 & 6.5 & \multirow{3}{*}{0.000} \\
\hline - Sufficient & 141 & 75.8 & 105 & 56.5 & \\
\hline - Good & 12 & 6.5 & 69 & 37.0 & \\
\hline \multicolumn{6}{|l|}{$\begin{array}{l}\text { Distance of } \\
\text { health facilities }\end{array}$} \\
\hline - Close distance & 111 & 59.7 & 57 & 30.6 & \multirow{2}{*}{0.001} \\
\hline - Long distance & 75 & 40.3 & 129 & 69.4 & \\
\hline \multicolumn{6}{|l|}{ Family support } \\
\hline - Give support & 174 & 93.5 & 162 & 87.1 & \multirow{2}{*}{0.224} \\
\hline - No support & 12 & 6.5 & 24 & 12.9 & \\
\hline Total & 186 & 100 & 186 & 100 & \\
\hline
\end{tabular}

\section{DISCUSSION}

This study investigated women who live in urban and rural areas in the Southeast Sulawesi. The largest age group of respondents who performed VIA test were 31-40 years old. This result was similar to previous studies that found the percentage who do not perform cervical cancer screening in the last 5 years was higher in women aged 23-29 years old and 60-65 years old. ${ }^{14}$

The majority of respondents were low parity and first sexual intercourse at the age of more than 17 years old. Although it was classifiedas low risk, however the VIA test was still needed to be conducted. There are several risk factors of cervical cancer, such as having sexual intercourse at a young age and high parity. ${ }^{1,2,15}$ Those who have been active sexually before the age of 16 years old have a risk of cervical cancer by 10-12 times greater than those aged 20 years old and over. Those who have children in the number above 5 will often experience trauma of the cervix, making it easier to change mucosal cells to be abnormal and closely related to the incidence of cervical cancer. ${ }^{16}$

VIA is used as an alternative screening and more encouraged, especially in developing countries. VIA is low-cost screening technologies. ${ }^{17}$ Respondents come from various segments of community. ${ }^{4}$ Respondents in this study have sufficient and less family income. This shows that the VIA test is an affordable examination. VIA test did not need much money and it was cheaper. ${ }^{2,4}$ This is unlike the results of previous study which find that the higher income level would get, the better practice of Pap's smears would perform. ${ }^{18}$ This condition is caused by Pap's smears test is more expensive than the VIA test. Economic factors contribute significantly to practice on VIA test. The ability to choose health care related to economic status. The higher income level of the community had, the better health practice of the community would get. ${ }^{19}$ Previous research in five countries found that using the VIA test carried out together at the time of cervical examination can reduce the incidence of cervical cancer and reduce costs. ${ }^{12,20}$

The majority of respondents in this study were workers. The result was similar to the previous studies, it showed that employment did not affect VIA test. ${ }^{7}$ It shows that the VIA test is easier to do because it can be done at primary health care, so that working women do not spend much time to leave their work.

In this study, most respondents in urban and rural areas have enough knowledge 
about cervical cancer and VIA test. This study reported that rural respondents have more good knowledge of cervical cancer than urban respondents. Knowledge is something known or recognized. Knowledge is obtained by performing empirically and rationally, it can also be obtained through a reasonable and logical thinking mind. Knowledge is influenced by factors of education, media, and information. ${ }^{18}$ Information and education can improve the knowledge so it contributes to the success of early detection program in rural areas. This result is similar to the previous studies that find the relationship between knowledge about cervical cancer with participation of VIA test. ${ }^{7}$

This study showed that respondents in rural areas had good knowledge of cervical cancer. It showed that health information and education had been successfully conducted in rural areas. Working area system of health center has made easier for officers to socialize and provide health information and education to the community. Although they have low education level, but good and intensive information both formal and informal will improve public knowledge. This study found that education level did not affect knowledge and VIA respondents. ${ }^{7}$ Knowledge of urban communities may be derived from self-generated information, and it is because the urban communities are busier than rural communities, so health information and education from officers cannot beperformed intensively.

Coverage of VIA testis related to distance of residence and health center. VIA more accessible because it can be done in primary health center. ${ }^{2,6}$ Practice is affected by the ease of access to health services. Access to health services is related to the distance of the health center. The closer the distance between recipients and service providers, the tendency to choose health services is higher. ${ }^{2,4}$ Tran et al. found that women in rural areas were reluctant to screen for cervical cancer because remote medical centers required more time and cost for screening. ${ }^{21}$
Practice was influenced by family support. Family support affected the tendency to choose practice that were appropriate for family support. ${ }^{8,18}$ This study found that the majorityof respondents in urban and rural areas had good family support. This result was similar to the previous studies that found the relationship between family support and interest in conducting VIA test. ${ }^{8}$ Family support might be affected by environmental factors. The social environment has a profound influence on health status, such as health beliefs, traditions, social and cultural interaction. According to Blum, the environment is one of the determinants of health status. Social and cultural environment influences the health status and health practice. Cultural factors contribute to disparities in health care. $^{18}$

Health practice can be influenced by internal and external factors. Similarly, the practice of cervical cancer screening is influenced by internal and external factors, which are predisposing factors, enabling factors and reinforcing factors. ${ }^{18}$

\section{CONCLUSION}

Based on the results study, we concluded that education level, knowledge, and distance of health facilities are determinants of cervical cancer screening coverage in urban and rural areas in Southeast Sulawesi. There are differences of education level, knowledge, and distance of health facilities for VIA test in urban and rural areas. There is no difference of family support for VIA test in urban and rural areas.

\section{ACKNOWLEDGEMENTS}

We would like to thanks all the parties who had contribute in this study. We also send our gratitude to all the women participants from Kendari and rural areas of South Konawe, Southeast Sulawesi for their participation on this study. 


\section{REFERENCES}

1. Ferlay J, Soerjomataram I, Dikshit $\mathrm{R}$, Eser $\mathrm{S}$, Mathers $\mathrm{C}$, Rebelo $\mathrm{M}$, et al. Cancer incidence and mortality worldwide: sources, methods and major patterns in Globocan 2012. Int J Cancer 2015; 136(5): E359-86.

https://doi.org/10.1002/ijc.29210

2. Direktorat Jendral PP \& PL. Pencegahan kanker payudara dan kanker leher rahim. Jakarta: Kementrian Kesehatan Republik Indonesia; 2011.

3. Nuranna L. Extending coverage and developing a network for achieving cervical cancer screening with documentation on visual inspection of acetic acid (Do-VIA) in Indonesia. Indones J Obstet Gynecol 2014; 2(2): 62-3.

4. Nuranna L, Purwoto G, Anggreni TD, Utami TW, Aziz MF, Andriyono. Skrining kanker serviks dengan IVA dan model aplikasi di lapangan. Edisi 2. Jakarta : Divisi Onkologi Ginekologi Departemen Obstetri dan Ginekologi Fakultas Kedokteran Universitas Indonesia; 2012: 21-2.

5. Anggraeni TD, Nuranna L, Chaterine C, Sobur CS, Rahardja F, Hia CW. Distribution of age, stage, and histopathology of cervical cancer: a retrospective study on patients at Dr.Ciptomangunkusumo Hospital, Jakarta Indonesia, 2006-2010. Indones J Obstet Gynecol 2011; 35(1): 21-4

6. Djayadilaga, Saifuddin AB, Daili SF, Wratsangka R, Mohamad K, Djauzi S. Langkah-langkah Praktis Paket Pelayanan Kesehatan Reproduksi Esensial. Ed. 2. Jakarta: Pusat kesehatan reproduksi FKUI; 2007.

7. Maharsie L \& Indarwati. Hubungan pengetahuan ibu tentang kanker serviks dengan keikutsertaan ibu melakukan IVA test di Kelurahan Jebres Surakarta. Jurnal Penelitian. 2012; 9(2): 46-54.

8. Rahma RA, \& Prabandari F. Beberapa faktor yang mempengaruhi minat WUS (wanita usia subur) dalam melakukan pemeriksaan IVA (inspeksi visual dengan pulasan asam asetat) di Desa Pangebatan Kecamatan Karanglewas Kabupaten Banyumas Tahun 2011. Jurnal Ilmiah Kebidanan. 2012; 3(1), $1-14$.

9. Darnindro N, Jasin MR, Martina, Heryanto L, Ardiansyah D, Tambunan $\mathrm{M}$, et al. Pengetahuan sikap perilaku perempuan yang sudah menikah mengenai pap smear dan faktor-faktor yang berhubungan di Rumah Susun Klender Jakarta 2006. Maj Kedokt Indon 2007; 57(7): 220-6.

10. Adefuye PO, Broutet NJ, de Sanjose S, Denny LA. Trials and projects on cervical cancer and human papillomavirus prevention in Sub-Saharan Africa. Vaccine 2013; 31 (Suppl 5): F53-9. https://doi.org/10.1016/j.vaccine.2012.06.070

11. Sherris J, Wittet S, Kleine A, Sellors J, Luciani S, Sankaranayaranan $\mathrm{R}$, et al. Evidence-based, alternative cervical cancer screening approaches in lowresource settings. Int Perspect Sex Reprod Health 2009; 35(3): 147-54. https://doi.org/10.1363/3514709

12. Belinson JL, Pretorius RG, Zhang WH, $\mathrm{Wu}$ LY, Qiao YL, Elson P. Cervical cancer screening by simple visual inspection after acetic acid. Obstet Gynecol 2001; 98 (3): 441-4.

http:/dx.doi.org/10.1097/00006250-200109000-00014

13. Saimin J. Studi komparatif cakupan deteksi dini kanker serviks dengan metode IVA pada 2 fasilitas pelayanan yang berbeda di Sulawesi Tenggara. Proceeding of the $7^{\text {th }}$ Scientific Meeting of Indonesian Obstetric and Gynecologic Association; 2014, February 10-12; Makassar, Indonesia.

14. Benard VB, Thomas CC, King J, Massetti GM, Doria-Rose VP, Saraiya $\mathrm{M}$, et al. Vital signs: cervical cancer incidence, mortality, and screening United States 2007-2012. MMWR Morb Mortal Wkly Rep 2014; 63(44): 1004-9.

15. Hacker NF. Cervical cancer. In :Berek JS, Hecker NF, editors. Practical 
gynecologic oncology, $5^{\text {rd }}$ ed. Philadelphia : Lippincott \& Wilkins, 2010: 342-88.

16. Alliance for Cervical Cancer Prevention. Natural history of cervical cancer: even infrequent screening of older women saves lives. Cervical Cancer Prevention Fact Sheet. 2003.

17. Huchko MJ, Sneden J, Zakaras JM, McCune KS, Sawaya G, Maloba M, et al. A randomized trial comparing the diagnostic accuracy of visual inspection with acetic acid to visual inspection with Lugol's iodine for cervical cancer screening in HIV Infected women. PLos One 2015; 10(4):e0118568 https://doi. org/10.1371/journal.pone. 0118568

18. Goldie SJ, Gaffikin L, GoldhaberFiebert JD, Gordillo-Tobar A, Levin
C, Mahe C, et al. Cost-effectiveness of cervical cancer screening in five developing countries. N Engl J Med 2005; 353(20):2158-68. https://doi.org/10.1056/NEJMsa044278

19. Notoatmodjo S. Promosi kesehatan dan perilaku kesehatan. Jakarta: Rinekacipta, 2012.

20. Depkes RI-JNPK. Kanker serviks di Indonesia, See and Treat. Jakarta : Departemen Kesehatan Republik Indonesia, 2007.

21. Tran NT, Choe SI, Taylor R, Ko WS, Pyo HS, So HC. Knowledge, attitude and practice (KAP) concerning cervical cancer and screening among rural and urban woman in six provinces of the Democratic People's Republic of Korea. Asian Pac J Cancer Prev 2011; 3029-33. 